$\begin{gathered}\text { Науковий вісник Нлту України } \\ \text { Scientific Bulletin of UNFU } \\ \text { https://nv.nltu.edu.ua }\end{gathered}$
$\begin{aligned} & \text { https://doi.org/10.36930/40310123 } \\ & \text { Article received 21.01.2021 p. } \\ & \text { Article accepted 04.02.2021 p. } \\ & \text { UDC 004.738.5:37.018:378.(057.87) }\end{aligned}$

Ю. І. Гриџюк, Т. П. Дяк

Національний університет "Львівська політехніка", м. Львів, Україна

\title{
ЗАСТОСУВАННЯ ІНТЕРНЕТ-ТЕХНОЛОГІЙ ДЛЯ ОРГАНІЗАЦІЇ НАВЧАЛЬНОГО ПРОЦЕСУ У ВИЩИХ НАВЧАЛЬНИХ ЗАКЛАДАХ
}

Розкрито особливості застосування інтернет-технологій для організації навчального процесу у ВНЗ, охарактеризовано переваги та недоліки їх використання, а також висвітлено основні проблеми на шляху інформатизації освіти в Україні. Проаналізовано можливості сучасних інтернет-технології, насамперед для надання послуг користувачам через хмарні сервіси, охарактеризовано моделі їх обслуговування, визначено актуальні тенденції розвитку хмарних сервісів у сфері освіти. Доведено, що новітні інтернет-технології й надалі будуть входити в усі сфери людської діяльності, у т.ч. наукову та освітню. Об'єктивні закономірності їхнього розвитку не дають змоги сподіватися на те, що вони стануть винятком і майбутнє у них буде повністю "безхмарним". Однак, певне відставання України щодо їх широкого запровадження надає можливість потенційним провайдерам проходити не всі етапи становлення інтернет-технологій, пропускаючи ті із них, що приносять більше негативних, ніж позитивних результатів. Прихильники ж інтернет-технологій - службовці, бізнесмени, науковці та студенти, потребуючи їх найбільше, мають можливість вчитися на чужих помилках і уникати власних. Прогнозовано, що використання хмарних сервісів у навчанні студентів - майбутнє освітнього процесу. Вони пропонують альтернативу традиційним формам організації навчального процесу у ВНЗ, створюючи можливість як для індивідуального навчання, проведення інтерактивних занять, так і колективного освоєння навчального матеріалу. З'ясовано, хмарні сервіси мають величезний науковий потенціал і відкривають широкі можливості не тільки для навчальних закладів, але й для пересічної особистості, що зацікавлена у своїй науковій діяльності. Встановлено, що широке впровадження хмарних сервісів у навчальний процес ВНЗ не тільки знизить витрати на придбання необхідного ПЗ, підвищить якість і ефективність організації освітнього процесу, але й надасть підгрунтя для подальшої успішної діяльності майбутніх фахівців у сучасному інформаційному суспільстві.

Ключові слова: інформаційне суспільство; інформаційні ресурси; вищий навчальний заклад; навчальний процес; інтернет-технології; хмарні технології; хмарні сервіси.

\section{Вступ}

Відомо [3, 18], мережа Інтернет на сьогодні є найважливішою соціально-економічною комунікацією між різними представниками нашої цивілізації. Вона відображає стан функціонування різних сфер людської діяльності та надає інформаційний сервіс для вільного їхнього спілкування незалежно від місця перебування. Як технічний засіб розвитку особистості мережа Інтернет істотно сприяє іiі самореалізації та розширює соціальні можливості для задоволення своїх потреб. Така мережа необхідна всім учителям і учням, викладачам і студентам, науковим керівникам і їхнім аспірантам незалежно від предмета, який вони вивчають, чи області знань, яку досліджують. Мережеві технології дали можливість об'єднати результати роботи багатьох автономних працівників і надали доступ до цих результатів всім, хто в них зацікавлений. Тому освітні та наукові галузі розвитку інтернет-технологій на сьогодні визначають основні напрями удосконалення інформаційних технологій загалом [10, 11].

Сучасні інтернет-технології призначені для створен- ня та підтримки різних інформаційних ресурсів [4]: сайтів, сервісів, блогів, форумів, чатів, електронних бібліотек і енциклопедій тощо. В їхній основі знаходяться гіпертексти і сайти, розміщені в глобальній мережі Інтернет або в локальних корпоративних мережах. Вони забезпечують миттєвий і повний доступ різних споживачів інформації до всього обсягу світових знань та набутого людством досвіду, що звільняє їх від потреби планувати та здійснювати багатоступеневу роботу для одержання тих чи інших знань, відомостей чи даних. Користувачі мережевих ресурсів не тільки "споживають" інформацію, а й постійно доповнюють ії різними новими даними - як достовірними, так і не зовсім, що вимагає зазвичай критичного ставлення до такої інформації.

Мережа Інтернет $є$ сучасним засобом надання однакового доступу охочим навчатися до якісної освіти, а також є невід'ємною складовою освітнього процесу як державних, так і приватних навчальних закладів. Освітні хмарні сервіси стали достойною альтернативою класичної моделі навчання, яку ще донедавна широко використовували в різних освітніх установах. Головною

Інформація про авторів:

Грицюк Юрій Іванович, д-р техн. наук, професор, кафедра програмного забезпечення. Email: yurii.i.hrytsiuk@lpnu.ua; https://orcid.org/0000-0001-8183-3466

Дяк Тетяна Петрівна, канд. пед. наук, доцент, кафедра прикадної лінгвістики. Email: tanyushkadyak@yahoo.com

Цитування за ДСту: Грицюк Ю. І., Дяк Т. П. Застосування інтернет-технологій для організації навчального процесу у вищих навчальних закладах. Науковий вісник НлтУ України. 2021, т. 31, № 1. С. 137-146.

Citation APA: Hrytsiuk, Yu. I., \& Dyak, T. P. (2021). The use os internet technologies in educational process in higher education institutions. Scientific Bulletin of UNFU, 31(1), 137-146. https://doi.org/10.36930/40310123

Науковий вісник НЛТУ України, 2021, т. 31, № $1 \quad$ Scientific Bulletin of UNFU, 2021, vol. 31, no 1 
їх перевагою стала істотна економія програмно-апаратних засобів навчального закладу, які вони б мали спочатку придбати, встановити, а потім використовувати для організації навчального процесу. Адже потужну комп'ютерну інфраструктуру й/або чималі інформаційні ресурси хмарні сервіси надають усім студентам, викладачам і науковцям як послуги віддаленого провайдера. Єдине, чим необхідно забезпечити учасників освітнього процесу для безперебійного навчання за допомогою хмарних технологій, - це мати постійний доступ до мережі Інтернет.

Під "хмарою" розуміють складну інфраструктуру 3 великою кількістю технічних деталей, захованих у відповідних сервісах, доступ до яких надають їхнім користувачам різні провайдери. Такі великі компанії, як Атаzon, Google, Microsoft і т.д., пропонують значні знижки навчальним закладам, викладачам і студентам, за рахунок чого вони отримують доступ до хмарних сервісів практично безкоштовно чи за невелику абонентську плату. Особливо це стосується самостійної роботи студентів у процесі проведення колективних навчальних досліджень. Тут першочергового значення набуває можливість постійного контакту студентів між собою, студентів 3 викладачами чи науковими керівниками задля забезпечення моніторингу якості їхньої роботи, а також оперативного управління навчальною діяльністю $[5,7]$.

Проте, розуміння потреби запровадження інтернеттехнологій в усі сфери людської діяльності, у т.ч. і в наукову та освітню, підтримка їх науковцями та викладачами власними освітніми матеріалами, а також державна підтримка їх запровадження у навчальний процес все ще знаходяться на низькому рівні, що значно перешкоджає успішній підготовці майбутніх фахівців згідно з сучасними вимогами суспільства.

Об'єкт дослідження - запровадження інтернет-технології в навчальний процес ВНЗ.

Предмет дослідження - методи і засоби застосування інтернет-технологій під час організації навчального процесу, що забезпечить однаковий доступ його учасників до отримання якісної освіти з будь-якого місця у будь-який час.

Мета роботи - розкриття особливостей застосування інтернет-технологій для організації навчального процесу у ВНЗ, дослідження переваг та недоліків їх використання, а також висвітлення основних проблем на шляху інформатизації освіти в Україні та пошук підходів до їх вирішення.

Для досягнення зазначеної мети визначено такі ocновні завдання дослідження: обгрунтувати потребу застосування інтернет-технологій у навчальному процесі ВН3, насамперед для надання освітніх послуг учасників процесу через хмарні сервіси; проаналізувати актуальні тенденції розвитку хмарних сервісів у сфері освіти, охарактеризувати моделі їх обслуговування та особливості наповнення новими інформаційними ресурсами.

Наукова новизна отриманих результатів дослідження - проаналізовано можливості застосування інтернеттехнологій для організації навчального процесу у ВН3, насамперед для надання послуг студентам через хмарні сервіси, охарактеризовано моделі їх обслуговування, визначено актуальні тенденції розвитку у сфері освіти та для наукової діяльності.

Практична значущість результатів дослідження встановлено, що об'єктивні закономірності розвитку но- вих інтернет-технологій не дають змоги сподіватися на те, що вони стануть винятком і майбутне у них буде повністю "безхмарним". Певне відставання України від їх запровадження надає можливість потенційним провайдерам проходити не всі етапи становлення хмарних технологій, пропускаючи ті них, що приносять більше негативних, ніж позитивних результатів.

Аналіз останніх досліджень та публікацій. Проведений аналіз наукової літератури свідчить про те, що на сьогодні, особливо під час всеосяжного карантину, достатньо актуальною $є$ проблема використання мережі Інтернет в освітньому просторі як студентів ВН3, так і учнів загальноосвітніх шкіл. Адже повноцінна підготовка майбутніх фахівців будь-якого профілю не можлива без використання інформаційних технологій, а випускник навчального закладу повинен вільно орієнтуватися у просторах інтернет-ресурсів [8] і вміти ефективно використовувати їхні можливості в своїй повсякденній діяльності. Питання, пов'язані з використанням інтернеттехнологій у навчальному процесі, розглядали такі вчені-педагоги, як: Ю. А. Бріскін, Є. С. Полат, О. В. Собаєва, Н. В. Беляева, А. С. Петров, М. Ю. Бухаркіна, Н. В. Ладиженська, Н. О. Шаповалова та ін.

Численні психолого-педагогічні дослідження проблеми застосування мережі Інтернет в освітньому процеci $[9$, c. 8], грунтовна характеристика дидактичного потенціалу новітніх хмарних сервісів $[6,27]$ і їхній вплив на організацію навчального процесу наведено в роботах таких науковців, як Н. Р. Балик, Л. В. Брескіна, Н. П. Дементієвська, П. М. Маланюк, Є. Д. Патаракін, І. М. Сокол, Г. В. Стеценко, В. В. Осадчий, Л. О. Флегантов, Г. П. Шмигер та інші. Водночас, такі науковці, як Г. В. Жабєєв, Ю. О. Жук, М. Ю. Кадемія, С. Г. Литвинова, С. А. Марченко, В. П. Олексюк, Т. О. Петрова, О. М. Соколюк, Г. В. Стеценко, В. М. Франчук та інші у своїх працях навели основні напрями застосування інтернеттехнологій у практиці навчання студентів.

Однак, у їхніх робота практично відсутній грунтовний аналіз можливості застосування сучасних інтернеттехнології для організації навчального процесу під час введення всеосяжного карантину, коли викладачам i студентам доводиться працювати віддалено, а ефективні методики надання послуг через хмарні сервіси ще не розроблено і не адаптовано для різних неординарних ситуацій, не охарактеризовано моделі їх обслуговування, не визначено актуальні тенденції розвитку хмарних сервісів у сфері освіти на найближчу перспективу, а також не достатньо обгрунтовано потребу застосування цих сервісів у навчальному процесі ВНЗ. Ці та багато інших нагальних освітніх питань спробуємо вирішити в цьому науковому дослідженні.

\section{Результати дослідження та їх обговорення}

На сучасному етапі розвитку суспільства освіта в багатьох розвинутих країнах надзвичайно швидко прогресує, кожного дня вона доповнюється все новими і новими методами та формами навчання. Одним із таких методів стало запровадження в навчальний процес інтернет-технологій, які відкривають широкі можливості у поданні студентам навчальних матеріалів, що підвищує ефективність отримання необхідної інформації та отримання нових знань. Адже знання старіють кожні 3-5 років, а технологічні знання - кожні 2-3 роки [15]. Пройде ще небагато часу і це буде вже 1,5-2,0 роки. Обсяг знань 
випускників ВНЗ подвоюється кожні 3-4 роки. Якщо не міняти освітніх технологій, то якість підготовки фахівців буде об'єктивно відставати від рівня, необхідного на сучасному ринку праці. Хоча в Україні за останнє десятиліття сучасні інтернет-технології активно й запроваджують в навчальний процес ВНЗ, але швидкість його реалізації не завжди задовольняє як надавачів, так і споживачів освітніх послуг. Особливо ця проблема проявила свою слабинку під час оголошення всеосяжного карантину, коли викладання дисциплін довелось проводити дистанційно, а викладачі й студенти були не тільки не забезпечені надійними технічними засобами відеозв'язку, але й елементарними навиками їх ефективного використання.

Отже, одним з видів організації навчального процесу в кризових ситуаціях $є$ введення дистанційного навчання [2], тобто використання сукупності інтернет-технологій, що забезпечують доставку студентам основного обсягу навчального матеріалу, створюють інтерактивну взаємодію студентів і викладачів у процесі навчання, надають студентам можливість самостійно виконувати поставлені завдання й передавати їх на перевірку. На відміну від заочного навчання дистанційне дає можливість охочим до навчання вчитися, перебуваючи на будь-якій відстані від навчального закладу і у будьякий час.

Застосування сучасних інтернет-технологій загалом змінює відносини педагога та учня, викладача й студента, наукового керівника і аспіранта. Вони стають партнерськими, спрямованими на досягнення загальної цілі - організації такого навчального процесу, в якому роль учителя чи викладача буде зводитися до його коригування чи управління цим процесом. Постійна апробація наявного матеріалу на студентах дає змогу викладачу удосконалювати свою педагогічну діяльність, вносячи до неї новітні інформаційні та дидактичні розробки [6, 27], не допускаючи застою чи морального старіння викладеного в них матеріалу.

Водночас, належний рівень мультимедійної компетентності викладача [17] вимагає від нього не тільки уміння здійснювати пошук необхідної інформації в мережі Інтернет, але й передбачає: знання роботи з хмарними сервісами; знання орієнтовного переліку наявних інтернет-ресурсів [8], можливості їх використання в навчальному процесі та самоосвітній роботі студентів; розроблення змісту та методик використання інформаційних ресурсів у навчально-виховному процесі; розроблення власних веб-сайтів і їх використання під час викладання свого предмету; уміння організувати самостійну освітню діяльність студентів 3 використанням інтернет-ресурсів.

1. Обгрунтування потреби застосування хмарних сервісів у навчальному процесі ВНЗ. При використанні хмарних сервісів потенційні споживачі хмарних послуг, наприклад, викладачі ВНЗ можуть істотно знизити капітальні витрати на побудову власної комп'ютерної інфраструктури, а саме - на придбання серверного та мережевого обладнання, на впровадження програмно-апаратних засобів щодо забезпечення їх безперебійної роботи та затребуваної потужності, позаяк ці витрати бере на себе їхній провайдер. Окрім цього, тривалий період побудови та введення в експлуатацію різних об'єктів власної комп'ютерної інфраструктури, а також висока їх початкова вартість значно обмежують можливість ВНЗ гнучко реагувати на пропозиції сучасного ринку наявного ПЗ. Водночас, провайдери хмарних сервісів мають можливість практично миттєво реагувати на збільшення попиту своїх користувачів на різні хмарні послуги чи відповідне ПЗ стосовно його потужності чи можливості, а також негайно встановлювати на свої серверах для загального використання. Водночас як активне використання хмарних сервісів у навчальному процесі ВНЗ їні витрати зміщуються в бік операційних можливостей пристроїв безпосередніх користувачів - викладачів і студентів, науковців і аспірантів, тобто в такий спосіб можна компенсувати витрати на оплату хмарних послуг відповідним провайдерам.

Отже, спробуємо з'ясувати деякі особливості організації процесу надання хмарних послуг студентам ВНЗ, тобто зупинимося на таких основних моментах: чому саме використовують термін "хмара"; наведемо моделі хмарних сервісів і їх характеристики; обговоримо можливість друкувати документи через хмарні сервіси; вияснимо проблему втрати важливих даних у хмарних сервісах; встановимо потребу поєднання хмарних сервісів зі стаціонарними комп'ютерами; вияснимо причину повсякденного використання хмарних сервісів студентами; встановимо, хто був потужним попередником хмарних сервісів. На ці та багато інших запитань спробуємо нижче дати вичерпні та аргументовані відповіді.

Потреба використання терміну "хмара". Багатьоx студентів молодших курсів цікавить, чому сервіси віддалених обчислень і оброблення даних називають саме "хмарними" [23]. На це запитання є декілька відповідей. Передусім, традиційне зображення мережі Інтернет на діаграмах комп'ютерних мереж виконують саме у вигляді "хмари" (рис. 1). Водночас, "хмара" - це символ віддаленості від конкретного користувача. Окрім цього, "хмара" - це образ складної комп'ютерної інфраструктури, за якою ховаються всі технічні деталі їі реалізації. Так що термін "хмара" - це, грубо кажучи, метафора, яка прижилася в ІТ-індустрії як один 3 найбільш вдалих термінів (за винятком нудного слова "віддалені"), що передає суть самого явища як такого. Хоча для студентів-початківців така назва часто вводить їх у ступор, а інколи й стимулює дізнатися, врешті-решт, що ж це за таке "хмарні сервіси". Адже хмарний сервіс дає змогу його користувачам працювати навіть 3 пристроєм, спочатку зовсім не призначеним для виконання такого виду робіт.

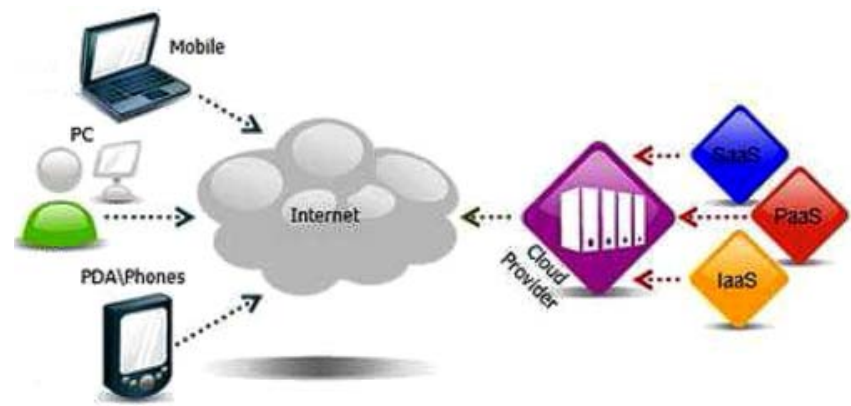

Рис. 1. Схема організації роботи за допомогою хмарного сервісу

Моделі хмарних сервісів і ̈̈х характеристика. Звичайно ж, хмарні технології $[20,21]$ не обмежуються сервісами Google Docs або Photoshop.com. У них є цілі підкатегорії, що різняться між собою за видом надання хмарних послуг. Спробуємо познайомитися з ними дещо ближче з економічної точки зору. 
1) Програмне забезпечення як сервіс, SaaS (англ. Software-as-a-Service) - це модель продажу й використання ПЗ, при якій провайдер розробляє веб-додаток і самостійно управляє ним, надаючи користувачам доступ до ПЗ через мережу Інтернет. При цьому всі витрати на підтримку його безперебійної роботи бере на себе провайдер, водночас, як користувач оплачує тільки сам факт використання "хмарного" ПЗ (або абонентську плату, якщо сервіс платний). Отже, користувачеві не треба відразу викладати значну суму грошей на придбання ліцензованого ПЗ, а розробник ПЗ і його провайдер захищені від несанкціонованого використання та поширення свого програмного продукту.

2) Платформа як сервіс, PaaS (англ. Platform-as-aService) - надання користувачу платформи 3 певними характеристиками для розроблення, тестування, розгортання, підтримки веб-додатків і т.д. Не секрет, що сьогодні більшість ПЗ розробляють в одному середовищі, тестують в іншому, а розгортають в третьому [19]. Завдяки PaaS-сервісу весь перелік цих операцій можна виконати в одному інтегрованому середовищі, тим самим уникнувши витрат на підтримку окремих середовищ для реалізації конкретних етапів розроблення ПЗ Це дає змогу його розробникам істотно знизити витрати як на придбання та підтримку власних програмно-апаратних засобів, так і на його обслуговування. Яскравий приклад використання такого хмарного сервісу - послуги хостингу для веб-сайтів.

3) Інфраструктура як сервіс, IaaS (англ. Infrastructure-as-a-Service) - використовують винятково компанії, позаяк простим користувачам абсолютно не потрібна. Це надання клієнту у використання різноманітної хмарної інфраструктури (серверів, систем зберігання даних, мережевого устаткування, а також ПЗ для управління цими ресурсами). Як правило, в такій системі застосовують різні технології віртуалізації, за якої конкретну одиницю устаткування можна використовувати декількома клієнтами (яскравий приклад - поділ фізичного сервера провайдера на віртуальні частини для їх надання різним клієнтам). Одна 3 головних переваг такого підходу полягає в тому, що компанії позбавлені потреби придбання дорогого устаткування, частина 3 якого може просто простоювати або виконувати роботу не на повну потужність. Кампанії платять тільки за те, що їм на даний момент потрібно з можливістю гнучкого збільшення або зменшення обсягу використаних комп'ютерних ресурсів. Прикладом подібних програм $\epsilon$ той же хмарний MS Office або "1C: Підприємство", а також деякі антивірусні рішення, які, окрім компаній, з успіхом використовують різні пересічні користувачі.

4) Програмний комплекс як сервіс, DaaS (англ. Desktop-as-a-Service) - при наданні цієї послуги компанії отримують повністю готовий до роботи (під ключ) стандартизований віртуальний комп'ютер, який можна додатково налаштувати під виконання своїх безпосередніх завдань. Отже, клієнт отримує доступ не до окремої програми, а до програмного комплексу, необхідного йому для повноцінної роботи. Приходячи на роботу, він просто вводить свої дані (логін/пароль або інші засоби автентифікації) й відразу ж може працювати, використовуючи для цього обчислювальні потужності сервера провайдера, а не свого власного комп'ютера.

5) Робоче місие як сервіс, WaaS (англ. Workspace-as$a$-Service), але, на відміну від DaaS, користувач отримує доступ тільки до ПЗ, водночас, як всі обчислення відбуваються безпосередньо на його власному комп'ютері. В цьому випадку потрібно придбати потужний і дорогий комп'ютер, якщо користувач хоче швидко виконати потрібні обчислення [23].

6) Все як сервіс, EaaS (англ. All-as-a-Service) - модель, що містить елементи всіх перерахованих вище рішень і $є$ на сьогодні швидше за все концептом для подальшої реалізації, ніж реально наявним механізмом відтворення. Запровадження подібної моделі очікують від таких гігантів, як компанії Microsoft, Google, Hewlett-Packard і т.д.

Як бачимо, моделей хмарних сервісів достатньо багато, але більшість 3 них орієнтована на бізнес-діяльність, тобто на тих, хто за надані хмарні послуги готовий платити, а не переживати за організацію потужної й дорогої власної комп'ютерної інфраструктури, яка більшість часу буде якщо не простоювати, то працювати максимум на третину потужності. 3 іншого боку, хмарних послуг, які можуть отримати звичайні користувачі, в т.ч. викладачі та студенти, за допомогою SaaS-сервісу, вже існує достатньо багато, більшість 3 яких поки що надають безплатно як рекламну акцію або за символічну абонентську платню. Тому можна сміливо констатувати той факт, що хмарні сервіси потрібні багатьом й, що найважливіше, їх активно використовують усі ті, хто про них знає й кому вони вкрай потрібні, частіше за все безоплатно. Але, як і все інше, хмарні сервіси мають й деякі недоліки, про які йтиметься дещо далі.

Можливість друкувати документи через хмарні сервіси. Хмарні послуги можна отримувати не тільки через мережу Інтернет, але й при роботі з конкретними пристроями. Так, компанія Hewlett-Packard має в багатьох своїх пристроях технологію НР ePrint. Завдяки їй принтери цієї компанії здатні роздрукувати будь-який документ, відправлений на принтер (а точніше, його унікальну поштову адресу) з будь-якого пристрою, що має доступ до мережі Інтернет і функцію відправлення електронної пошти (у т.ч. і з мобільного телефону). Зазвичай, в цьому випадку не потрібне встановлення драйверів й іншого спеціального ПЗ - все це знаходиться на хмарних серверах компанії Hewlett-Packard, звідки і здійснюють друкування документа. Ознайомитися 3 повним переліком принтерів "HP ePrint - как использовать", що підтримують дану технологію, можна за такою адресою: http://printerprofi.ru/hp/eprint.html.

Проблема втрати важливих даних у хмарних сервicax. Коли блакитне літнє небо раптом темніє, а на зміну красивим, купчастим і білим хмарам приходять грозові та чорні хмари, стає не до жартів - треба швидше ховатися від дощу і блискавки, яка навряд чи потрапить у вас, але може вдарити в дерево, під яким ви ховаєтеся. Аналогічно і $з$ хмарними сервісами, адже проблеми вони теж можуть доставляти як потенційним, так і постійним користувачам. Одна з головних таких проблем передача важливих даних у треті руки, після чого їх власник повністю втрачає контроль над ними.

Якщо для пересічних користувачів (в т.ч. викладачів i студентів) це й не настільки критично (хоча тими ж соціальними мережами також потрібно користуватися 3 розумом), то для бізнес-компаній це може стати проблемою - промислове шпигунство ще ніхто не відміняв. Можливе й перехоплення даних під час їх відправлення 
на сервер провайдера або використання зловмисниками фішингових і підставних сайтів для виманювання персональних даних під виглядом добропорядної "хмарки" (рис. 2).

Нагадаємо, що фішинг (англ. Phishing - рибальство) - вид шахрайства, метою якого є виманювання у довірливих або неуважних користувачів мережі Інтернет персональних даних клієнтів он-лайн аукціонів, сервісів 3 переказу або обміну валюти, інтернет-магазинів. Фішинговий сайт - це шахрайський веб-ресурс, який виманює реквізити платіжних карток під виглядом надання послуг, що не існують (наприклад, поповнення мобільного рахунку, переказів з картки на картку), або веб-ресурс організації, якій користувач довіряє (наприклад, клон інтернет-банку), що має на меті збирання реквізитів платіжних карток для подальшої крадіжки грошових коштів 3 рахунків отримувачів платіжних карток. Більше 90 \% фішингових сайтів надають фіктивні послуги з поповнення мобільного рахунку та переказу коштів 3 картки на картку.

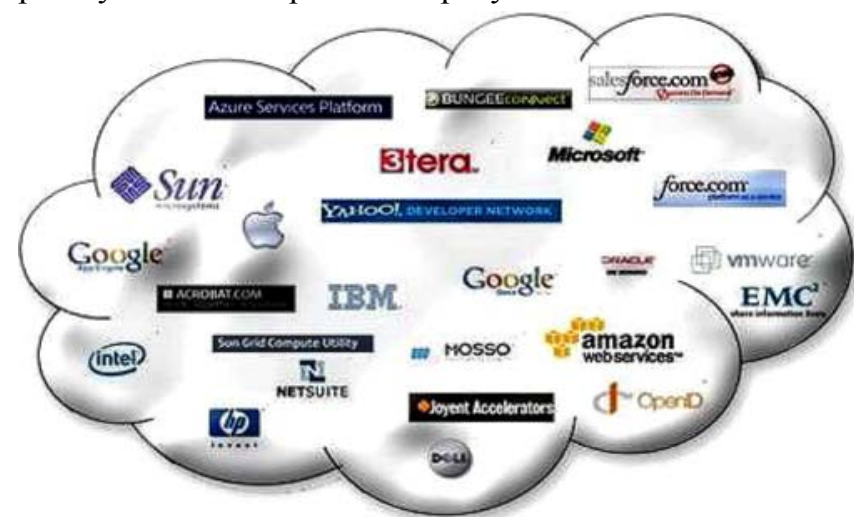

Рис. 2. Перспективність розвитку хмарних сервісів для великих гравців IT-ринку

Окрім цього, персональні дані, які зберігають на хмарних серверах провайдерів, погано піддаються контролю іiі власником. Наприклад, багато соціальних служб і хмарних сервісів не мають опції повного видалення даних. Тобто, візуально їх видаляють, але найчастіше вони продовжують зберігатися на сервері провайдера. I хто знає, хто, коли і як їх буде потім використовувати. $€$ й інші моменти, наприклад, деякі он-лайнові ресурси не дають змоги локально зберігати проміжні результати роботи ПЗ, а без доступу в мережу користуватися подібними сервісами взагалі не можна. Загалом, проблем і загроз більше, ніж достатньо, але заради реальної справедливості та святих наукових ідей варто відзначити, що локальна робота навіть на власному комп'ютері теж не завжди безпечна на всі $100 \%$.

Поєднання хмарних сервісів зі стаціонарними комп'ютерами. Немає ніякого сумніву, що хмарні сервіси, пропоновані за різними моделями їхньої роботи, будуть успішно розвиватися й далі. Підтвердженням такого обнадійливого висновку $є$ те, що вже сьогодні їх існує значна кількість (див. рис. 2). Наприклад, ще в 2010 році концепція надання комп'ютерних ресурсів була започаткована в операційній системі Chrome OS від компанії Google (див. hi-Tech PRO 3/2010). Сама "операційка" стаціонарного комп'ютера займала мінімум місця й фактично була розширеною версією веб-браузеpa, за допомогою якого користувачі здійснювали доступ до різних хмарних сервісів. Звичайно, впевнено стверджувати, що й інші операційні системи 3 часом повністю перейдуть на подібну модель роботи, не варто, позаяк ще багато користувачів-консерваторів надто вже звикли до роботи за стаціонарним комп'ютером. Швидше за все, через декілька років, особливо після оголошення всеосяжного карантину, коли доводиться працювати не на офісному, а на власному комп'ютерному обладнанні, варто очікувати появу нових версій популярних операційних систем (як MS Windows, так і інших платформ). Такі системи матимуть якусь гібридну модель роботи - як з широкою підтримкою хмарних сервісів, так і звичною можливістю працювати безпосередньо на своєму комп'ютері. Зрозуміло тільки одне - 3 такими темпами, якими розвивається IT-індустрія, чекати цього залишилося не надто довго, і попередня наша оцінка в декілька років може бути навіть трохи завищеною.

Можливість повсякденного використання хмарних сервісів. На сьогодні хмарних сервісів у мережі Інтернет надзвичайно багато i, що найсмішніше, чималу кількість 3 них кожен 3 нас вже давно використовує, якось і не замислюючись над тим, що вони "хмарні". Серед офісних пакетів можна назвати вже згадувані Google Docs i MS Office, а також Zoho Writer. Багато хто 3 нас за допомогою подібних хмарних сервісів вміють не тільки оформляти документи, а й експортувати та імпортувати (конвертувати) файли з інших форматів, а також перекладати та перевіряти орфографію зручною для нас мовою. Охочі помалювати залюбки використовують такі хмарні сервіси, як Photoshop.com, Pixlr i Lunapic, а охочі створювати презентації (викладачі чи студенти) можуть успішно застосувати сервіс Sliderocket. Навіть створити власний веб-сайт без наявності глибоких знань 3 веб-програмування та спеціального ПЗ можна за допомогою різних хмарних сервісів, наприклад, скориставшись сервісом FastEsite. Ну а такі імена хмарних сервісів, як LastFM, Pandora, Flickr, YouTube, Facebook, MySpace i т.д. особливої реклами не потребують.

Потужний попередник хмарних сервісів. Якщо хтось думає, що хмарні технології - це тренд останніх років, то він не зовсім правий [20, 21]. Так, у класичному вигляді подібні технології з'явилися відносно недавно. Але серед багатьох науковців побутує думка, що вони мали достойну попередницю - технологію розподілених обчислень. За допомогою неї можна було вирішити трудомісткі обчислювальні завдання, використовуючи декілька комп'ютерів, об'єднаних у паралельну обчислювальну систему. У реальному ж житті такий підхід до роботи застосовували ще в XVIII ст. у Франції для виконання навігаційних розрахунків і тих, що вимагали прийняття швидких рішень. В комп'ютерних системах такий алгоритм вперше був використаний в 1973 році, коли Джон Шох і Джон Хапп 3 каліфорнійського науково-дослідного центру Xerox PARC написали програму, яку ночами запускали в локальну мережу і змушували різні комп'ютери виконувати певні обчислення. Один 3 найбільш відомих програмних проектів, що використовував розподілені обчислення, - SETI@home, який був запущений ще в травні 1999 року на базі платформи BOINC. Його метою було пошук позаземного розуму шляхом аналізу даних 3 радіотелескопів. Що найцікавіше, найпотужніший сучасний супер-комп'ютер Cray-1 за обчислювальними можливостями поступається цьому проекту приблизно в два рази (2,3 проти 5,2 петафлопс). 
Нагадаємо, що SETI@home (від англ. Search for Extra-Terrestrial Intelligence at Ноте - пошук позаземного розуму вдома) - науковий некомерційний проект добровільних обчислень на платформі BOINC, що використовував вільні обчислювальні ресурси на комп'ютерах добровольців для пошуку радіосигналів позаземних цивілізацій. Водночас, Cray-1 - легендарний суперкомп'ютер, спроектований Сеймуром Креєм після того, як він пішов 3 компанії CDC, і створений компанією Cray Research Inc. в 1976 році. Пікова продуктивність машини становила 133 Мфлопс.

Підсумовуючи все наведене вище, можна стверджувати, що хмарні технології й надалі будуть входити у широкий вжиток в усіх сферах людської діяльності, у т.ч. і в наукову та освітню $[20,21]$. Об'єктивні закономірності розвитку нових хмарних сервісів не дають змоги сподіватися на те, що вони стануть винятком і майбутнє у них буде повністю "безхмарним". Однак, певне відставання багатьох країн (в т.ч. й Україні) у їх запровадженні від світових тенденцій їх розвитку надає можливість потенційним провайдерам проходити не всі етапи становлення хмарних технологій, пропускаючи ті із них, що приносять більше негативних, ніж позитивних результатів. Адже прихильники хмарних сервісів - службовці, бізнесмени, науковці та студенти, маючи в них найбільшу потребу, мають можливість вчитися на чужих помилках і уникати власних.

2. Актуальні тенденції розвитку хмарних сервісів у сфері освіти. За визначенням О. О. Гриб'юка [13], хмара - це великий пул легко використовуваних і доступних віртуалізованих інформаційних ресурсів - обладнання, платформи розробки та/або сервіси. Водночас 3. С. Сейдаметова [28] це поняття трактує як складну інфраструктуру з великою кількістю технічних деталей, захованих від їх користувачів. 3-поміж найбільш поширених освітніх сервісів і систем називають Black board, Moodle, Microsoft Live@edu, Google Apps для освіти, Групи Google [28]. Масового розповсюдження хмарні сервіси набули після запровадження компанією Google платформи Google Apps для розроблення веб-додатків. Загалом, наразі основними провайдерами хмарних сервісів є Amazon, Google, Saleforce [21].

Моніторинг інформації, поданої в мережі Інтернет [25], дав змогу з'ясувати, що на даний час існує низка досліджень, направлених на використання хмарних сервісів у навчальному процесі, вивчення загальних педагогічних особливостей їх впровадження в систему освіти, використання хмарних технологій у дистанційному навчанні під час оголошення карантину. Лідером у сфері комерційних хмарних сервісів Н. В. Морзе [23] вважає компанію Microsoft, яка пропонує відповідні рішення своїм користувачам за допомогою Microsoft Online Services та платформи Windows Azure. В. П. Олексюк [25], наводячи свій власний досвід інтеграції різних хмарних сервісів у інформаційно-освітній простір ВН3, вказує основні напрями застосування хмарного ПЗ, серед яких найбільшу перспективу має розгортання відповідних служб Google Apps. Результатом інтеграції цієї служби з власними веб-сервісами навчального закладу може стати успішна організація гібридного інформаційно-освітнього простору ВНЗ.

Втім, останнім часом популярності набувають хмарні сервіси, за допомогою яких викладач отримує мож- ливість розробляти не тільки власні веб-сервіси, а й вносити в них можливість опитування студентів за допомогою тестів. Прикладом такого хмарного сервісу для швидкого та якісного розроблення власних тестів $€$ система OpenTest [31]. Вочевидь, застосування таких хмарних сервісів має позитивний вплив на якість освіти майбутніх студентів, оскільки вони можуть не тільки вивчати викладений матеріал, але й перевіряти якість його освоєння, що для викладача є свого роду підказкою для подальшого коригування своїх дій. Доцільність проведення тестового контролю для оцінювання навчальних досягнень студентів вже доведена багатьма фахівцями і не викликає сумнівів у їхній достовірності [4, $6,10]$.

Як наголошує 3. С. Сейдаметова, хмарні технології для ВН3 від Google мають деякі переваги, серед яких головними виступають мінімальні вимоги до апаратного забезпечення, відсутність потреби мати спеціальне ПЗ, підтримка всіх операційних систем і клієнтських програм, можливість використовувати для роботи з документами будь-якого мобільного пристрою, що підтримує роботу в мережі Інтернет, а також відсутність плати за інструменти Google Apps Education Edition [28].

Одним з напрямів застосування хмарних сервісів у освітній діяльності ВНЗ за оцінками А. І. Газейкіної [12] $є$ переміщення в хмару системи управління процесом навчання LMS (англ. Learning Management Systems). Безпосередня підтримка таких LMS як Blackboard i Moodle зовнішніми провайдерами дає змогу освітнім установам заощаджувати кошти на закупівлю та підтримку власного дорогого обладнання та відповідного ПЗ. В цьому випадку найбільш поширеним напрямом використання хмарних сервісів є застосування моделі хмари "Програмне забезпечення як сервіс" SaaS (англ. Software-as-a-Service). Серед інших таких технологій особливе значення має сервіс Google Docs (документи Google), за допомогою якого студенти мають можливість виконувати сумісні проекти, обговорювати їх особливості реалізації, публікувати результати виконання в мережі Інтернет, для подальшого аналізу та оцінювання викладачем створювати зведені таблиці й діаграми, а також проводити тестовий контроль і самоконтроль якості навчальних досягнень. Окрім зазначеного сервісу, інструментами цієї технології є електронна пошта Gmail, календар Google, диск Google - сховище для зберігання власних файлів, сайти Google - інструмент, який дає змогу створювати сайти за допомогою стандартних шаблонів [12].

Хмарний сервіс Microsoft Office 365 для освітніх установ дає змогу користуватися всіма можливостями різних хмарних служб, допомагаючи студентам економити час та кошти, а також значно підвищує їх працездатність [16]. Серед найбільш відчутних переваг розробники цього сервісу називають можливість проведення віртуальних занять та використання сайтів груп, які дають змогу студентам "тримати руку на пульсі" процесу навчання [22].

Сучасні хмарні сервіси дають змогу значно покращити якість підготовки студентів ВНЗ та значно збільшити контакт викладача із студентами. Для побудови ефективної системи управління процесом навчання (LMS) студентів за допомогою відповідних служб хмарних сервісів під час вивчення різних дисциплін Ю. Г. Лотюк [21] пропонує у приватній хмарі університету 
розмістити електронні навчальні посібники, які мають містити теоретичний матеріал, та лабораторні практикуми 3 прикладними завданнями для виконання практичних чи лабораторних робіт. Для цього найкраще застосовувати комп'ютерну систему Moodle, яка сприятиме вдосконаленню процесу підготовки студентів до занять, а також дає їм змогу бачити всі результати їхньої освітньої діяльності. Наявність такої навчальної літератури в поєднанні із хмарними сервісами дає можливість студентам доповнювати свої знання з будь-якого місця перебування в будь-який час доби, маючи доступ до віддалених освітніх ресурсів. Що ж робити з паперовим варіантом такого навчального матеріалу, то його варто видавати в обмеженій кількості, щоб вистачило на обов'язкове розсилання в бібліотеки та на презентаційні витрати. Стосовно гонорару їх авторам, то мала б бути чимала премія від ВНЗ тільки за їхне якісне наповнення навчальним матеріалом і успішну підготовку до видання.

М. А. Шиненко у своїй праці [29] розкриває функціональні можливості хмарних сервісів під час організації дистанційного навчання, тобто навчання за допомогою хмарного сервісу Google Groups, моніторингу якості освіти за допомогою сервісу Google Docs, впровадження системи аналітики за допомогою сервісу Google Analytics. Підтримуючи думку автора, що зазначені можливості хмарних сервісів доцільно реалізувати в ВНЗ для організації дистанційного навчання тільки тих студентів, які з різних причин не можуть бути присутні на заняттях. Застосування таких технологій на час відсутності студента забезпечує йому вільний доступ до навчальних матеріалів і створює ефект присутності на заняттях і консультаціях.

Ще більш корисним джерелом зарубіжного досвіду для науковців і освітян може стати дослідження, проведене аналітиками Companies Gartner [1, 14, 30], щодо визначення актуальних тенденцій розвитку хмарних сервісів у сфері освіти. Результати цього дослідження адресовані тим фахівцям, що відповідають за їхнє впровадження в навчальний процес та управління наявними інтернет-ресурсами [8]. У цьому дослідженні також зазначено, що на сучасному етапі розвитку IT-індустрії для підтримки системи освіти найбільш впливовими трендами є хмарні сервіси та консумеризація (залучення особистих електронних пристроїв працівників для виробничих потреб). Їхній вплив поступово зростав протягом останнього десятиліття і зараз, особливо під час всеосяжного карантину, можна стверджувати про їхній справжній технічний успіх, що панує не тільки в багатьох ВН3, але й багатьох шкільних освітніх закладах. Очевидним $є$ прогрес у конкретних сферах (електронні адреси для студентів у хмарному сервісі чи управління ідентифікацією особи та доступом до ресурсів) та загальне спрямування на побудову так званої "гнучкої інфраструктури". Це саме стосується й IT-галузі, де більшість іiі працівників виконують свою роботу віддалено, переважно на своєму комп'ютерному обладнанні.

У пошуках відповіді на запитання, чи не варто ВНЗ повернутись до усталених традицій організації освітнього процесу і сконцентрувати свою увагу на продуктивності університету (факультету, студента), компанія Gartner [14] вважає, що вдосконалення власної комп'ютерної інфраструктури наразі $є$ пріоритетним завданням для будь-якого навчального закладу. Тут йдеться тільки про те, що раніше було просто "інфраструктурою", а не "ціною за вхід" до освітнього процесу чи науково-дослідного "бізнесу", де багатьма викладачами і студентами сприймається як ключова стратегія розвитку сучасного навчального закладу, яка мала б не відставати від світової тенденції розвитку ІТ-галузі. Вважаємо, що у словосполученні "гнучка інфраструктура" головним є слово "гнучка", позаяк з різних причин (брак коштів у ВНЗ на поновлення комп'ютерного обладнання чи оголошення карантину i, як наслідок, вимушеного дистанційного навчання) навчальному закладу все ж таки доведеться іiі організовувати. Сучасні ВН3 завжди були й мають залишатися безпечною гаванню для запровадження різноманітних технологічних інновацій $[24,26]$, що базуються на академічній свободі їхнього вибору $[1,30]$. Водночас, сучасні хмарні сервіси мають сприяти інтеграції інноваційного потенціалу викладачів і студентів у межах їх особистої працездатності, тобто вони мають бути гнучкими для реалізації як своїх потреб, так і презентації своїх можливостей.

Для хмарних сервісів, актуальних у сфері надання освітніх послуг, у 2019 році увійшли шість нових інноваційних напрямів [26], що пов'язані із консумерацією залученням особистих електронних пристроїв працівників для виробничих потреб. Вони стали новим джерелом постачання інформаційно-технологічних ресурсів, які можуть використовувати викладачі та студенти в усіх підрозділах навчального закладу (рис. 3). Такими інноваційними напрямами є:

1) Campus App Store, концепт на зразок iOS App Store чи Google Play, але призначений для однієї конкретної навчальної установи чи середовища $з$ певним обслуговуванням (наприклад, кампусу - університетського містечка). Ідея полягає у тому, що новий студент чи працівник, використовуючи власний електронний пристрій, отримує доступ до програмних додатків, необхідних йому в процесі навчання чи виконання іншої роботи. Цей сервіс призначений для підтримки більш, ніж однієї платформи.

2) бездротовий зв'язок як послуга WaaS (англ. Wireless-as-a-Service) - у освітньому контексті йдеться про те, коли має місце купівля ВН3 безпровідних послуг у зовнішнього провайдера для доповнення чи заміни власного мережевого доступу. Оскільки освітні, дослідницькі та адміністративні послуги все частіше затребувані їхніми користувачами як хмарні послуги, то надійний доступ до мережі Інтернет стає не тільки фундаментальним, а й життєво необхідним. Безпроблемний доступ - основа мобільного навчання, тобто навчання у стані он-лайн. Адже викладачі та студенти розраховують на безперебійну роботу навчальних хмарних сервісів у будь-який час і з будь-якого місця.

3) Bring Your Own Device (BYOD) - політика "принеси свій власний пристрій" дає змогу значно скоротити витрати на технічне забезпечення навчального процесу. Нові групи студентів, що вступають кожного року на навчання, приносять із собою широкий асортимент пристроїв і звичку отримувати відповідні хмарні послуги. Комп'ютерні відділи ВНЗ просто не в змозі зупинити хвилю різноманітних приватних електронних пристроїв, тому вони намагаються знайти у цьому переваги i перетворити їх на допоміжний навчальний інструментарій.

4) Learning Stack (навчальний стек) поєднує певний перелік компонент, таких як: різноманітні програмні 
додатки, персональні виробничі IT-інструменти, Webдодатки, контент-репозиторії, джерела даних, доступ до яких здійснюють, наприклад, через соціальні навчальні платформи. Сховище $є$ динамічним, різні компоненти можна додавати, вилучати чи замінювати. Розвиток i впровадження цього концепту пов'язані насамперед із процесом розробленням відкритої структури соціальної навчальної платформи.

5) Email for Faculty and Staff (електронна пошта для співробітників і викладачів), який надає Office 365 - це університетська система електронної пошти для керівництва і працівників, викладачів і студентів, аспірантів i науковців. Це хмарний сервіс від Microsoft, який управляє електронною поштою, календарями, переліком завдань та адресними книгами (https:/it.cornell.edu/

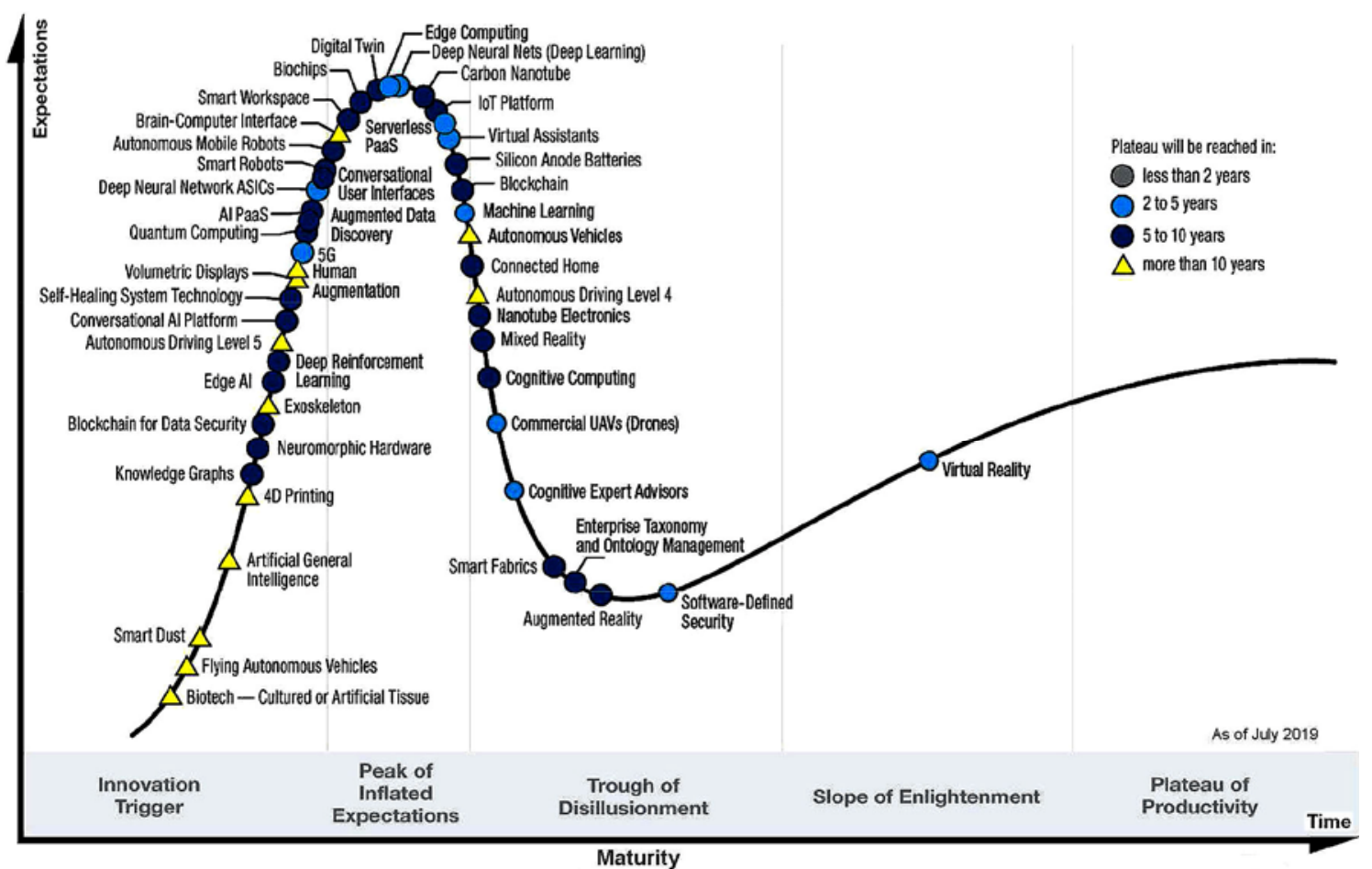

Рис. 3. Цикл надмірних сподівань для хмарних сервісів у освіті [30]

3 огляду на все зазначене вище, можна впевнено стверджувати, що використання хмарних сервісів у повсякденній роботі бізнесмена чи науковця, студента чи учня - має успішне майбутнє. Вони пропонують альтернативу традиційним формам організації навчального процесу у ВНЗ, створюючи можливість як для персонального навчання, проведення інтерактивних занять i колективного виконання освітніх робіт. Хмарні сервіси мають величезний потенціал i відкривають широкі можливості не тільки для навчальних закладів, але й для будь-якої людини, що зацікавлена в одержанні якісної освіти. Впровадження хмарних сервісів у навчальний процес ВНЗ не тільки знизить витрати на придбання необхідного ПЗ, підвищить якість і ефективність організації освітнього процесу, але й підготує майбутніх випускників до життя в сучасному інформаційному суспільстві.

\section{Висновки}

Внаслідок проведення дослідження розкрито особливості застосування інтернет-технологій для організації навчального процесу у ВНЗ, досліджено переваги та недоліки їх використання, а також висвітлено основні проблеми на шляху інформатизації освіти в Україні та facstaff-email). Студенти й випускники використовують G Suite for Student, раніше відомий як Cmail.

6) Gamification (гейміфікація від англ. Game - гра) використання ігрових механізмів у не розважальному середовищі. Як відомо, гра споконвіку є однією з основних форм ефективної організації навчального процесу та зручним засобом подачі інформації, що дає змогу викладачам організовувати навчальний процес більш цікавим, а тому і більш простим. "Серйозні ігри" можна використовувати як засіб моделювання для протиаварійних тренувань та для вирішення бізнес-завдань в освіті, науці, охороні здоров'я, воєнній справі та ін. Гейміфікація освітнього процесу грунтується на природному прагненні людини (особливо молодої) до цікавого спілкування, тому їй прогнозують успішне майбутнє. наведено шляхи їх вирішення. За результатами її виконання можна зробити такі висновки:

1. Проаналізовано можливості застосування інтернет-технології для організації навчального процесу у ВН3, насамперед стосовно надання послуг користувачам через хмарні сервіси, охарактеризовано моделі їх обслуговування, визначено актуальні тенденції розвитку хмарних сервісів у сфері освіти, а також обгрунтовано нагальні потреби їх застосування у навчальному процесі ВНЗ.

2. Доведено, що новітні інтернет-технології й надалі будуть входити в усі сфери людської діяльності, у т.ч. і в наукову та освітню. Об'єктивні закономірності їх розвитку не дають змоги сподіватися на те, що вони стануть винятком і майбутне у них буде повністю "безхмарним". Однак, певне відставання багатьох країн, в т.ч. й України щодо запровадження хмарних технологій надає можливості потенційним провайдерам проходити не всі етапи їх становлення, пропускаючи ті із них, що приносять більше негативних, ніж позитивних результатів. Прихильники ж хмарних технологій - службовці й бізнесмени, науковці та студенти, потребуючи їх найбільше, мають можливість вчитися на чужих помилках і уникати власних. 
3. Прогнозовано, що використання хмарних сервісів у навчанні школярів і студентів - майбутнє освітнього процесу. Вони пропонують альтернативу традиційним формам організації навчального процесу ВНЗ, створюючи можливість як для персонального навчання, проведення інтерактивних занять, так і колективного освоєння навчального матеріалу. З'ясовано, що хмарні сервіси мають величезний науковий потенціал і відкривають широкі можливості не тільки для навчальних закладів, але й для будь-якої особистості, що зацікавлена в одержанні якісної освіти. Впровадження хмарних сервісів у навчальний процес ВНЗ не тільки знизить витрати на придбання необхідного ПЗ, підвищить якість і ефективність організації освітнього процесу, але й підготує до життя майбутніх фахівців у сучасному інформаційному суспільстві.

\section{References}

1. About Companies Gartner. (2013). Companies Gartner Inc. Companies Gartner, Inc. and/or its Affiliates, $124 \mathrm{p}$. Retrieved from: http://www.Companies Gartner.com/technology/aboutj sp

2. Aman, I. S., \& Litvinenko, O. V. (2016). Internet services in the open space: a methodical book. Kirovohrad, 88 p. Retrieved from: https://sites.google.com/site/sch10iteach/biblioteka/internetservisivosvitnomuprostori. [In Ukrainian].

3. Balabanova, E. E., \& Vakarev, E. S. (2013). Victory of social fringes at professional performance vicladac VNZ. Science notes. Series: Pedagogy, 3, 135-136. Retrieved from: http://dspace.tnpu.edu.Ua/bitstream/123456789/3612/1/BALABANOVA.pdf. [In Ukrainian].

4. Bikov, V. Yu. (2011). Khmarni technologies, IKT-outsourcing and new functions of IKT for education and science installations. Information technology in education, 10, 8-23. [In Ukrainian].

5. Black, O. V. (2012). Using a cycle of over-expectations to identify trends in cloud services. Cloud technologies in education: materials of the All-Ukrainian scientific-methodical Internet-seminar, (pp. 3-6), December 21, 2012, Kryvyi Rih - Kyiv - Cherkasy Kharkiv, Ukraine. Kryvyj Rig: Publishing department KMI. [In Ukrainian].

6. Buzhikov, R. P. (2011). The didactic potential of Internet technologies in the current system of education. Problems of education: scientific collection of the Institute of Innovation Technologies and Education of the Ministry of Education and Science of Ukraine, 66(II), 41-42. [In Ukrainian].

7. Chorna, O. V., Kharadzhyan, N. A., Shokalyuk, S. V., \& Moiseenko, N. V. (2013). Global trends in cloud services. Theory and methods of e-learning, IV, 272-284. Kryvyj Rig: Publishing department KMI. [In Ukrainian].

8. Christoph, S. D. (2011). The use of Internet resources to improve the quality of the teaching process of natural sciences and mathematics in secondary school. Proceedings. Series: Pedagogy, 5, 134, 136-137. Retrieved from: http://dspace.tnpu.edu.ua/bitstream/123456789/1671/1/Krushtof.pdf. [In Ukrainian].

9. Christoph, S. D. (2012). Preparation of future teachers of natural sciences and mathematics for the use of Internet support in the process of teaching high school students. Abstract of Candidate Dissertation for Pedagogical Sciences (13.00.04 - Theory and methods of vocational education). Kharkiv, 18 p. [In Ukrainian].

10. Dementievskaya, N. P., \& Morse, N. V. (2005). Computer technology for the development of students and teachers. Information technologies and teaching aids: collection of scientific works, (pp. 76-95). Kyiv: Ataka. [In Ukrainian].

11. Dzyubenko, A. A. (2000). New information technologies in education. Moscow: Publishing house "Science", 104 p. [In Russian].

12. Gazeykina, A. I., \& Kuvina, A. S. (2012). The use of cloud technologies in the process of teaching schoolchildren. Information technology in education, 6, 55-59. [In Russian].
13. Gribyuk, O. O. (2016). Prospects for the introduction of cloud services in education. Retrieved from: http://lib.iitta.gov.ua/ 1111/1/grybyuk-stattyal-hmary\%2B_Copy.pdf. [In Ukrainian].

14. Hype Cycle Research Methodology. (2012). Companies Gartner Inc. Companies Gartner, Inc. and/or its Affiliates, 110 p. Retrieved from: http://www.Gartner.com/technology/research/methodologies/hype-cycle.jsp

15. Kiyanovska, N. M. (2013). The model of using information and communication technologies in the fundamental training of future engineers: the experience of the United States. Theory and methods of e-learning, (Vol. IV, pp. 122-133). Kryvyj Rig: Publishing department KMI, $360 \mathrm{p}$. [In Ukrainian].

16. Krutova-Onikienko, O. O. (2018). Blended learning is organized using Office 365. Retrieved from: http://oko1578.blogspot.com/ p/blog-page_65.html. [In Ukrainian].

17. Kuzminskaya, O. (2010). Ensuring the conditions for acquiring professional competence of teachers in the information society. New pedagogical thought: scientific and methodical magazine, 2, 107-111. Rivne. [In Ukrainian].

18. Levchenko, O. M., Koval, I. V., \& Zavadsky, I. O. (2009). Basics of the Internet: a textbook. Kyiv: Publishing Group BHV, 320 p. [In Ukrainian].

19. Litvinova, S. G. (2016). Design of a cloud-oriented educational environment of a higher educational institution: monograph. Kyiv: CP "Comprint", 354 p. [In Ukrainian].

20. Litvinova, S. G., \& Tebenko, O. V. (2013). Cloud technologies. Touch Develop social programming environment. Computer at school and family. Scientific and methodical journal, 5, 26-32. [In Ukrainian].

21. Lotyuk, Yu. G. (2013). Cloud technologies in the educational process of universities. Psychological and pedagogical bases of humanization of educational process in school and high school, 1, 61-67. [In Ukrainian].

22. Microsoft. (2017). Overview of Microsoft Cloud Education Services for Education. Retrieved from: http://shkolaedu.softline.ru/uploads/documents/03f2fa9a615c16515cfd3f62195f072a9276367e.pdf.

$[\operatorname{In}$ Russian].

23. Morse, N. V., \& Kuzminska, O. G. (2011). Pedagogical aspects vikoristannya khmar-them enumeration. Information technologies in education: a collection of scientific papers, 9, 20-21. [In Ukrainian].

24. Nanaeva, T. V. (2010). Innovation programs of INTEL corporation. Computer at school and family. Scientific and methodical journal, 6, 3-5. [In Ukrainian].

25. Oleksyuk, V. P. (2013). Experience integrating Google Apps cloud services into the information and education space of a higher education institution. Information technologies and teaching aids, 35(3), 64-73. [In Ukrainian].

26. Rafalska, O. O. (2013). Technology of change of knowledge yak innovation of distance education. Computer-integrated technologies: education, science, production. Scientific journal, 11, 128133. [In Ukrainian].

27. Services. (2016). Services for creating didactic materials. Retrieved from: http://ow.ly/ZS5x9. [In Ukrainian].

28. Seydametova, Z. S., \& Seitvelieva, S. N. (2011). Cloud services in education. Information technology in education, 9, 104-110. [In Russian].

29. Shinenko, M. A., \& Soroko, N. V. (2012). Use of cloud services for professional development of teachers (foreign experience). Information technology in education, 206-214. [In Ukrainian].

30. Trending In Education. (2020). Gartner Hype Cycle 2020 - People Centric and Smart Spaces. Fler avsnitt av Trending In Education. Retrieved from: https://poddtoppen.se/podcast/1150805729/ trending-in-education/gartner-hype-cycle-2020-people-centricand-smart-spaces.

31. Vakalyuk, T. A. (2013). Possibilities of using cloud services in education. Current issues of modern pedagogy. Proceedings of the international scientific-practical conference, (pp. 97-99), Ostrog, November 1-2, 2013. Kherson: Helvetica Publishing House. [In Ukrainian]. 


\section{THE USE OS INTERNET TECHNOLOGIES IN EDUCATIONAL PROCESS IN HIGHER EDUCATION INSTITUTIONS}

The paper investigates some peculiarities of the use of Internet technologies for the organization of the educational process in higher education institutions, paying special attention to the advantages and disadvantages of their use in particular. The main problems of the development of education informatization in Ukraine are highlighted. The possibilities of modern Internet technologies, first of all providing cloud based services to users, are analyzed; the models of their maintenance are characterized as well. Some modern tendencies of development of cloud based services in the field of education are defined. In the course of our research we have proved that the latest Internet technologies will continue to be included in all spheres of human activity both in science and education. The objective laws of their development do not allow expecting them to become an exception and their future to be completely "cloudless". However, a certain lag of Ukraine in terms of their widespread implementation allows potential providers to miss some stages of development of Internet technologies, skipping those that bring more negative than positive results. Such advocates of Internet technology as employees, businessmen, scientists and students who need them the most have the opportunity to learn from the mistakes of others and avoid their own. The use of cloud based services in the training of students is supposed to be the future of the educational process. They offer an alternative to traditional forms of organization of the educational process in higher education institutions providing an opportunity both for individual learning, interactive classes, and also for students collective learning. Cloud based services are revealed to have a huge scientific potential and to open a wide range of opportunities not only for education institutions, but also for the average person interested in obtaining high quality education. To conclude, the widespread introduction of cloud based services in the educational process in higher education institutions will both reduce the cost of purchasing the necessary software, increase the quality and efficiency of the educational process, and also prepare for further activities of future professionals in the modern information society.

Keywords: information society; information resources; higher education institutions; learning process; internet technologies; cloud technologies; cloud services. 